\title{
配管外側移動ロボットの開発
}

\section{Development of Out-Pipe Robot}

\section{○学 濱田 実(富山大·院） 正 佐々木 基文（富山大・エ）正 小泉 邦雄(富山大・エ) 正 笹木 亮(富山大·工) 正 木下 功士(富山大·工)}

\begin{abstract}
-Minoru HAMADA Motofumi SASAKI, Kunio KOIZUMI, Tohru SASAKI, Kohji KINOSITA, Dept.of Mechanical and Intelligent Systems Eng. Univ of Toyama.,3190 Gofuku,Toyama,930-8555
\end{abstract}

Key Words: Out-pipe robot, Holding force

\section{1 緒言と目的}

石油・化学プラントなどの配管外側検査は人手に頼ってい る.人手に頼ることにより, 高所や狭险な空間といった悪環 境下での作業は困難である。また，人手による作業は検査結 果にばらつきがあり検査の均一性と信頼性にも問題がある. 加えて, この種の仕事は $3 \mathrm{~K}$ (污い, きつい, 危険) として 敬遠されているので, 物理的経済的にも難しい. 検査の精度 向上を図るためにも，ロボットによる検査作業の自動化が望 まれており，配管外側を移動するロボットが必要である。

これまでにも一定の配管径において吸盤を用いて配管を 把持するもの, アクチュエータで車輪を押し付ける方法, 配 管にゴム板を巻きワイヤで締め付ける把持方法といった配 管外側を移動するロボットが製作されている.また，配管径 が異なる場合においても正六角形の4辺を直進運動すること により配管を把持する機構がある.

しかし，配管が水平に設置された場合，過去に製作された 配管外側を移動するロボットは頂上に乗せるか, 底面に着い た状態での直進・スパイラル走行しか考慮されていない. 配 管の真横に設置した状態での走行は配管外周にロボットが 存在しない空間を利用して $\mathrm{T}$ 字管などといった配管の一部 にある障害物を越えるための機構を使用せず走行すること が望ましい.

本研究では，ある配管径の範囲内で配管を把持し，車輪を 用いて移動する機構を考えた.ロボットが水平配管の真横に 設置しても直進走行が可能であることを目指す．また，口ボ ットが配管を把持する際, どのような態勢でいても姿勢が保 持するのに必要な把持力を求めた。

\section{2 機 構}

今回製作した配管外側移動ロボット(Fig.1)は，ロボット移 動機構とリンク機構に大きく分かれる. ロボット移動機構は アクチュエータ(DC モータ)と歯車群を用いて駆動輪に伝動 することに配管軸方向に走行する. リンク機構はアクチュエ 一タ(DC モータ)と歯車群を用いて左右のアームを直進運動 させることにより配管を把持する役割を持つ.ロボット移動 機構とリンク機構は共にロボット本体部に存在する. 全長 $138[\mathrm{~mm}]$, 全幅 $87[\mathrm{~mm}]$, 全高 $53[\mathrm{~mm}]$, 総質量 $\mathrm{M}=0.330[\mathrm{~kg}]($ 口 ボット本体 $\left.\mathrm{m}_{\mathrm{B}}=0.286[\mathrm{~kg}], ア ー ム ~ \mathrm{~m}_{\mathrm{A}}=0.022[\mathrm{~kg}]\right)$ となった.

この配管外側移動ロボットの特徵として, ある配管径の範 囲内において配管軸方向から観察した場合, 配管径が異なっ てもロボット本体とアームの把持位置が配管中心角を 3 等分 するように把持する(Fig.2). 把持検出方法はリンク機構にあ るアクチュエータ(DC モータ)に流れる電流を測定すること
により必要以上の電流が流れると DCモータが停止するので, これを把持検出とする. また, 配管外周にロボットの構造が 存在しない空間を持つことにより，配管の一部に障害物があ るときはその空間を利用して障害物を越えることができる.

\section{3 把持力}

ロボット自身の重力に対して，どのくらいの把持力があれ ば配管上においてどのような態勢でいても姿勢が保持でき るか考えた. Fig.3 は配管径 D が水平に設置され配管外側移 動ロボットが配管中心に回転角 $\theta$ だけ傾いた図である.

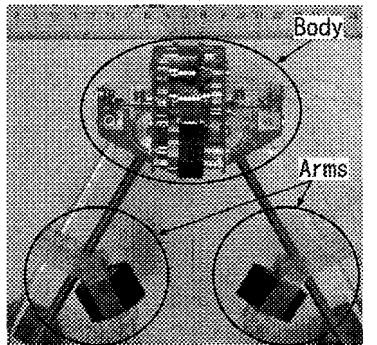

(a) Front

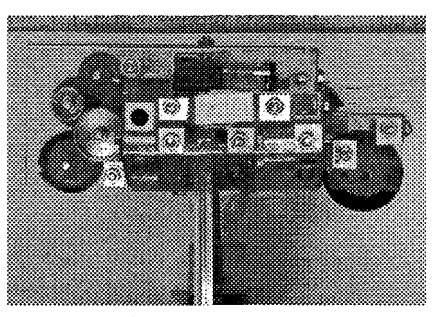

(b) Side (a) $\phi 30$

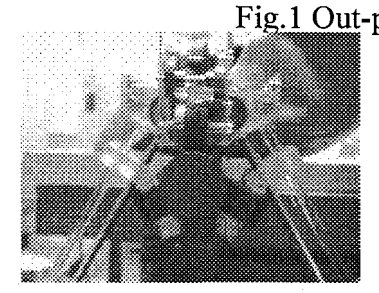

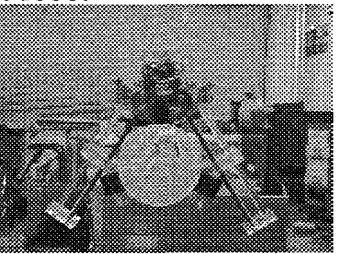

(b) $\phi 65$ Fig. 2 Holding

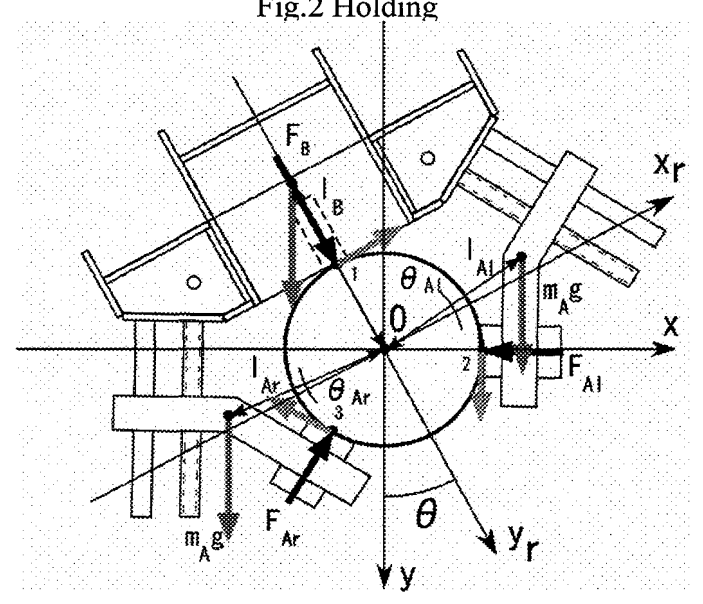

Fig.3 Out-pipe robot is holding 
ロボットが姿勢を保持するとき, ロボット本体, 各アーム の重力によって発生するトルクと配管と各車輪間で生じる 摩擦力によるトルクが等しい. 摩擦力はリンク機構のアクチ ユエータによる締付 $\left(\mathrm{F}_{\mathrm{Al}}=\mathrm{F}_{\mathrm{ar}}=\mathrm{F}, \mathrm{F}_{\mathrm{B}}=\mathrm{f}(\mathrm{F})\right)$ とロボット本体・各 アームの重力 $\left(\mathrm{m}_{\mathrm{B}} \mathrm{g}, \mathrm{m}_{\mathrm{A}} \mathrm{g}\right)$ によって生じる. 配管中心からアー ム重心までの距離 $\mathrm{l}_{\mathrm{A}}\left(=\mathrm{l}_{\mathrm{Al}}=\mathrm{l}_{\mathrm{Ar}}\right)=\mathrm{f}(\mathrm{D})$, ロボット本体における把 持点から重心までの距離 $\mathrm{l}_{\mathrm{B}}=\mathrm{f}(\mathrm{D}), \mathrm{x}_{\mathrm{r}}$ 軸とアーム重心と原点 $\mathrm{O}$ との線分とのなす角 $\theta_{\mathrm{A}}\left(=\theta_{\mathrm{Al}}=\theta_{\mathrm{Ar}}\right)=\mathrm{f}(\mathrm{D})$, そして配管と車輪 との摩擦係数がすべての把持部分において等しいとき, ロボ ットが姿勢を保持するのに必要な把持力 F は はig.4のように なる. Fig.4 の縦軸 F/Mg は「総重力 $\mathrm{Mg}$ に対して把持力 F は 何倍必要か」という意味を持つ無次元值で横軸が回転角 $\theta$ で ある. Fig.5には $\theta=90[\mathrm{deg}]$ における配管径が異なった場合の 無次元值 $\mathrm{F} / \mathrm{Mg}$ である.

Fig.4 において, $0 \leqq \theta \leqq 4.5[\mathrm{deg}]$ において F/Mg<0 となって いるが, この時はロボット本体, 各アームの重力が把持力と して十分に役割を果たしていることをさす. Fig.4，5で配管 径 D が大きくなると姿勢を保持するのに必要な把持力 $\mathrm{F}$ が 小さくなるのは, 配管径が小さいとき, ロボット本体の重力 位置と各アームの重力位置との距離が短くなり, ロボット本 体の重力 $\mathrm{m}_{\mathrm{B}} \mathrm{g}$ と各アームの重力 $\mathrm{m}_{\mathrm{A}} \mathrm{g}$ が一体化するからであ る.配管径が大きいときは, 口ボット本体の重力位置と各ア 一ムの重力位置との距離が長くなり， $\mathrm{x}_{\mathrm{r}} \mathrm{y}_{\mathrm{r}}$ 座標において各ア 一ム重心がロボット本体重心とは配管をはさんで逆の位置 になり, 各アームの重力によるトルクがロボット本体の重力 によるトルクを軽減するからである.

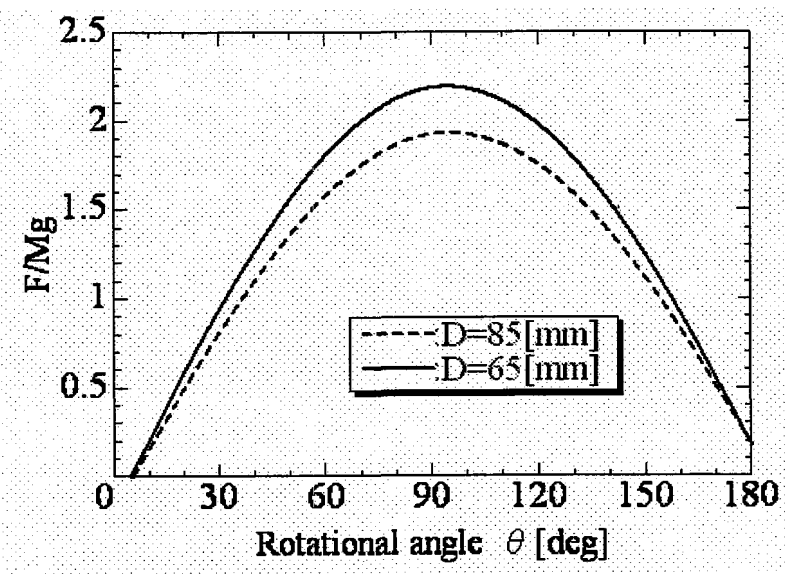

Fig. $4 \mathrm{~F} / \mathrm{Mg}$ vs. $\theta \quad(\mu=0.3)$

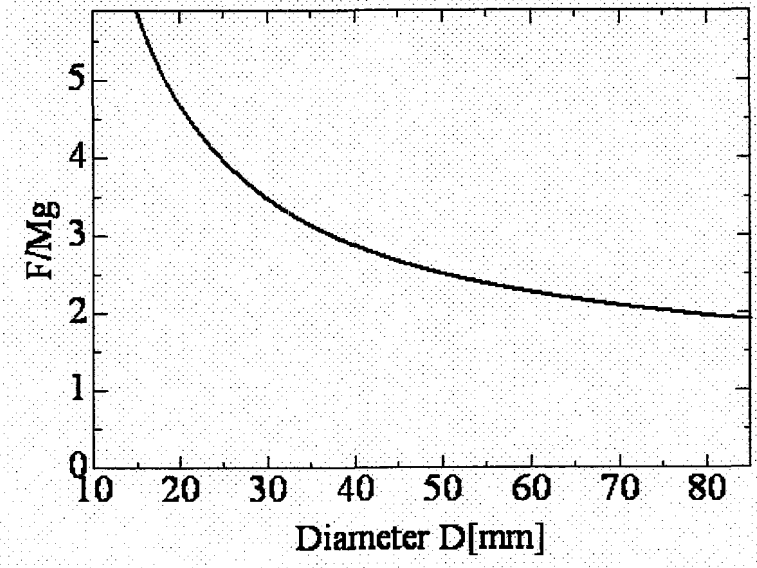

Fig. 5 F/Mg vs. D $(\mu=0.3)$

\section{4 実 験}

今回，配管外側を移動させるのに配管直径 $\mathrm{D}=65[\mathrm{~mm}]$ のア クリル管を用いた. ロボットが回転角 $\theta=0,45,90,135,180$ [deg] それぞれ傾いているときの移動実験をした．Fig.6 は実際の 移動の様子を，Fig.7 は画像解析により把持完了時の位置を 原点としたときの移動後のロボットの位置 $\mathrm{z}[\mathrm{mm}]$ と回転角 $\theta$ [deg]を示す.

Fig.7 の解析で $\mathrm{z}$ 軸から離れているとき, ロボットは本体 部の重力によって配管外周を回転しながら移動しているこ とを意味する．実験では配管軸方向の移動は確認できたが, Fig.7 のように特に $\theta=90[\mathrm{deg}]$ ではロボット本体の重力 $\mathrm{m}_{\mathrm{B}} \mathrm{g}$ によって不本意なスパイラル走行になってしまった.

\section{5 結 言}

今回の発表において以下のような結言を述べる.

1) $\theta=0,180[\mathrm{deg}]$ において配管外側移動を確認した.

2) ロボットが姿勢を保持するのに必要な把持力を求めた.

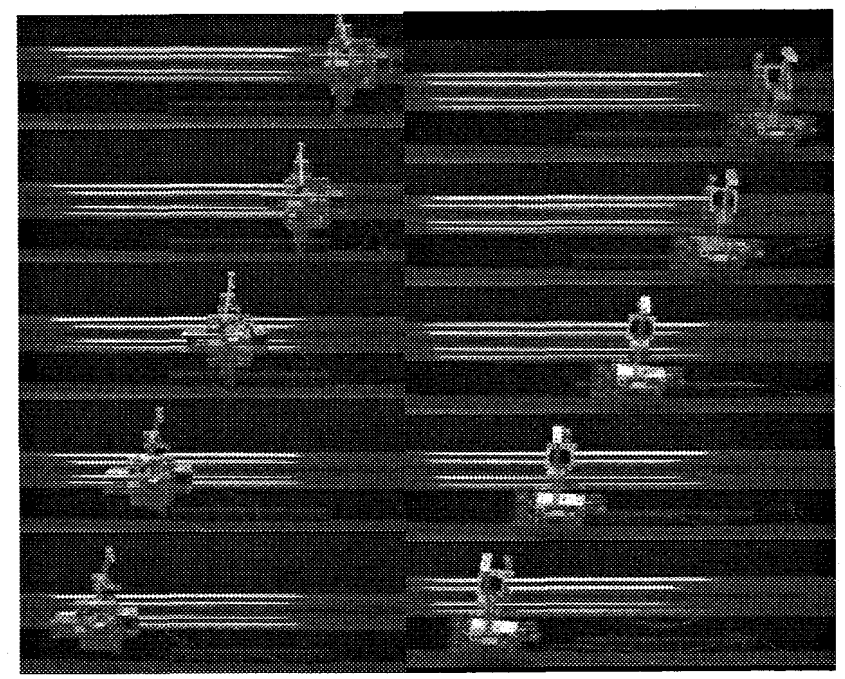

(a) $\theta=90[\mathrm{deg}]$

Fig.6 Move

(b) $\theta=180[\mathrm{deg}]$

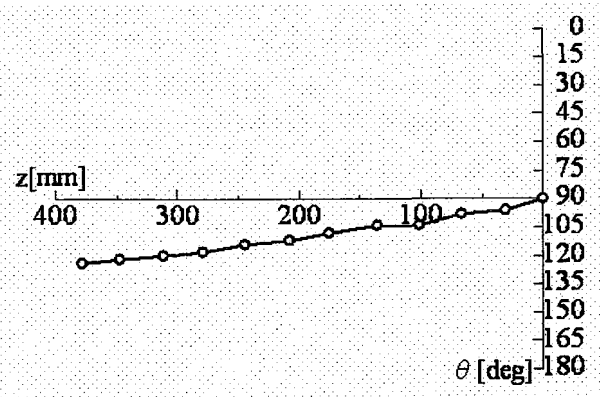

(a) $\quad \theta=90[\mathrm{deg}]$

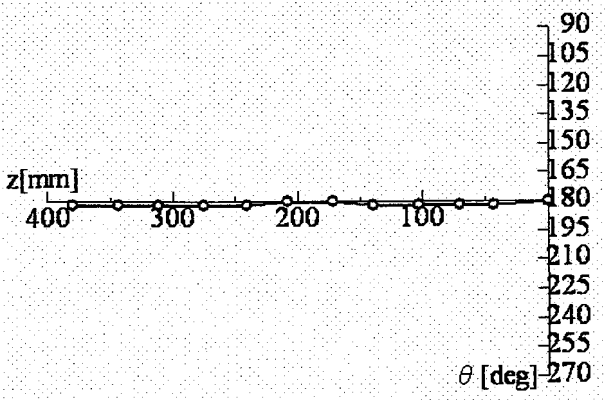

(b) $\theta=180[\mathrm{deg}]$

Fig. 7 Trace of movement 